\title{
THE IMPACT OF PROJECTED CHANGES IN THE TEXTILE AND APPAREL INDUSTRIES \\ ON THE ECONOMY OF THE SOUTHEAST: COMMEN T
}

James M. Stepp

Clemson University

The authors of this paperindicate that they have two general objectives: (1) to describe and analyze the changes in the level and regional distribution of employment in the textile and apparel industries from 1950 to 1970, and (2) to examine possible national and regional employment trends in the two industries between 1970 and 1980. Virtually all of the regional discussion deals with the 12 -state area which the authors designate as the "Southeast," no sub-regions within the area are delineated or discussed. The two industries are considered separately in some parts of the paper, and jointly in other parts. The paper presents on a state and regional basis data on the amount of employment in the textile manufacturing industry and the apparel industry in all of the states and regions of the nation for 1950, 1959, 1967 and 1970; gives national data onvalue-added per worker in the two industries for the same period; relates clothing expenditure trends to disposable income trends, and gives a fairly detailed tabular summary of textile imports and their relation to domestic production and sales.

My three general criticisms of the paper, whichwill be discussed separately, are as follows: First, the 12 states 1 designated as the "Southeast Region" comprise too large and too diverse an area to constitute a meaningful unit for interregional economic analysis of certain specific industries, especially the textile industry. Second, it is not appropriate or desirable to lump together the textile manufacturing industry and the apparel industry for purposes of discussing national and regional employment trends despite the fact that most apparel is made from textiles and some Federal agencies lump them together for statistical reporting purposes. And third, the authors neglected to adjust dollar values to compensate for changes in relative prices despite the fact that such changes were fairly substantial during the period covered by their study.

\section{DELINEATION OF REGIONS}

The view that the 12 states from Arkansas and Louisiana east to the Atlantic Ocean and south of the Potomac and Ohio Rivers may not always constitute an appropriate regionfor meaningful economic analys is is supported by Floyd and Fields' data on the textile manufacturing industry. It is true that for the 12 -state area as a whole textile employment increased by 71,791 workers between 1950 and 1970. However, the increase for the two Carolinas and Georgia was 72, 824, which was 1, 033 more than the total for the 12 -state region. The comparatively small gains and losses in the other 9 states balanced out with a net loss of 1,033 textile jobs. It is clear that the traditional 12 -state Southeast cannot be considered an appropriate unit for analyzing geographical and regional changes in the textile manufacturing industry.

Passing over historical considerations associated with the Civil War and its aftermath, it would appear just as logical to group the 15 Atlantic coastal states ${ }^{2}$ together as a region for purposes of economic analysis, as has long been done with the Pacific coastal states. I rearranged Floyd and Fields' textile employment data on the basis and discovered what appeared to be a most remarkable regional stability in the textile industry between 1950 and 1970. In 1950 my newly-invented Altantic Coastal Region had 85.1 
percent of the nation's textile employment, and in 1970 it had 84.8 percent -a change of less than one-half of one percent.

I am not suggesting seriously that the 15 Atlantic coastal states should be treated collectively as an economic region, but I am suggesting that the South Atlantic and South Central portions of the Southeast should betreated as two separate regions, especially for purposes of studying the textile industry. Between 1950 and 1970 the 6 South Central states covered by Floyd and Fields' study lost 6, 365 textile jobs, while the 6 South Atlantic states (including West Virginia) gained 78, 156 textile jobs, with over two-thirds of the gain occurring in one state - - North Carolina. None of the 6 Atlantic coastal states (except West Virginia, which is not really a coastal state) had a decrease in textile employment from 1950 to 1970 , whereas half of the 6 central states had decreases. Reporting in terms of 12 -state regional totals and averages conceals rather than reveals the fact that there was apparently a strong tendency in the 1950's and 1960's for the textile manufacturing industry to become concentrated in a fairly small geographical area along the South Atlantic coast rather than become dispersed throughout the 12 -state Southeast Region.

\section{THE APPAREL INDUSTRY}

The 12 -state area studied by Floyd and Fields is a much more appropriate unit for studying the apparelindustrythan for studying the textile manufacturing industry, although for the apparelindustryalso there is a substantial difference between the 6 eastern-most states and the other 6 states in the Southeast Region. Apparel employment increased in every one of the 12 states between 1950 and 1970, and the percentage shares of national employment in the industry more than doubled in both of the 2 sub-regions of the 12 -state area. Relative gains were considerably larger for the 6 South Atlantic states than for the 6 South Central states - - 174 percent as compared with 117 percent, but this difference does not appear to be large enough to impair the value of treating the 12 -state Southeast Region as a unit for purposes of analyzing the apparel industry.

However, it is noteworthy that practically all ( 82.3 percent) of the decrease in the Mid-east Region's share of the national apparel industry occurred in New York, and most of the remainder occurred in neighboring New Jersey. This, along with the data on other states and regions, suggests that the apparel industry, unlike the textile industry, is in the process of being dispersed following a prior condition of relative geographical concentration. Also, the two industries displayed opposite trends in total employment between 1950 and 1970; for the nation as a whole, apparel employment increased by 12 percent while textile employment decreased by 22 percent. The fact that both have been shifting southward during the past two decades does not appear to be sufficient grounds for lumping them together for purposes of analyzing national and regional employment trends and prospects.

\section{CHANGES IN RELATIVE PRICES}

The failure of Floyd and Fields to adjust their data to compensate for relative price changes caused them to make some dubious statements about changes in worker productivity in the textile and apparel industries, which may, initurn, have influenced their appraisal of the future prospects for growth of these industries. Between 1950 and 1970 the wholesale price index for all industrial commodities (except farm products and food) rose by 41.0 percent, whereas the comparable indexfor textile products and apparel rose wholesale price of textile products and apparel fell by 26 percent as compared with all industrial commodities, or, what amounts to the same thing, 
the wholesale price index for all industrial oommodities, based on 1950, was 35 percent higher than the comparable index for textiles and apparel.

If relative changes in worker productivity are to be measured by the value added per worker, as is done by Floyd and Fields, it is necessary to use an appropriate price index to adjust the data for each industry group before making any comparisons. My rather hasty calculations indicated that from 1954 to 1967 the productivity of labor increased by 68 percent for all manufacturing industries, by 65 percent for the apparel industry, and 93 percent for the textile industry. 4 In other words, the increase in labor productivity during this 13 -year periodwas some 36 percent greater in the textile industry than in all manufacturing industries combined, and the increase in productivity per worker was about the same for the apparel industry as for manufacturing as a whole. This, of course, is a somewhat different picture than that indicated by the raw data which are reported by Floyd and Fields.

A number of the conclusions reached by Floyd and Fields need to be reexamined on the basis of revised estimates of comparative changes in labor productivity. For example, it may be that the outlook for future growth of one or both of the two industries studied may be brighter than is suggested if it is not necessary for them to go through a catch-up period of improving labor productivity. There is a hint of this in the fact that, after declining from 1950 to 1967, textile employment increased slightly from 1967 to 1970-which was exactly opposite to the behavior of total manufacturingemployment, which increased from 1950 to 1967 and then decreased slightly from 1967 to 1970 .

\section{ADDITIONAL CONSIDERATIONS}

In addition to the foregoing comments relating to the delineation of appropriate geographical areas, the combining of industries, and.adjustments for relative price changes, there are three other more or less minor items which I shall cover very briefly. First, the authors apparently used valueadded per worker as a proxy for capital investment per worker without explaining why or discussing the extent to which the relationship is or is not proportional or dependable.

Second, Floyd and Fields conclude that, in contrast to earlier periods, the growth of the textile and apparel industries in the Southeast in the 1970's is unlikely to be much different than that of the Nation. It is probable that the southward shift of the textile industry is virtually over for the simple reason that practically all of the nation's textile industry is now located in the South. Such, however, is not the case with the apparel industry, and the authors give no convincing reasons why the movement of that industry from New York and New Jersey to the Southeast should not continue throughout the 1970 's.

And thirdly, Floyd' and Fields conclude that opportunities to increase per-capita incomes in the Southeast by increasing low-wage jobs have either ceased to exist or will soon do so. This proposition requires much more study and analysis than my time permits, but I am convinced that such a study would reveal dozens of counties in the Southeast where per-capita incomes would be increased considerably by new industries with average wage rates only slightly above the legal minimum. For people interested in regional and area economic development to ignore these possibilities because such industries have little leverage for increasing the average income for a whole state or region would be to fall into the same error that many Agricultural Extension Service workers made 3 or 4 decades agowhen they devoted most of their attention to the larger, more efficient farmers and largely ignored the small, inefficient farmers who really needed help. 
${ }^{1}$ Alabama, Arkansas, Florida, Georgia, Kentucky, Louisiana, Mississippi, North Carolina, South Carolina, Tennessee, Virginia, and West Virginia.

${ }^{2}$ Maine, New Hampshire, Massachusetts, Rhode Island, Connecticut, New York, New Jersey, Pennsylvania, Maryland, Delaware, Virginia, North Carolina, South Carolina, Georgia, and Florida.

${ }^{3}$ Statistical Abstract of the United States, 1971, p. 335. 